\title{
Anna SAKSON
}

Uniwersytet im. Adama Mickiewicza w Poznaniu

\section{UTRATA BEZPIECZEŃSTWA ŻYWNOŚCIOWEGO JAKO ŹRÓDLO WEWNĘTRZNYCH KONFLIKTÓW ZBROJNYCH W DARFURZE}

Zagadnienie bezpieczeństwa żywnościowego jest ściśle związane ze zjawiskiem głodu i niedożywienia, o których skali informacji dostarcza Organizacja Narodów Zjednoczonych ds. Wyżywienia i Rolnictwa (ang. Food and Agriculture Organization - FAO). Według najnowszych danych, odnoszących się do lat 2010-2012, na świecie ludzi głodnych i niedożywionych było około $870 \mathrm{mln}$, czyli co ósma osoba spośród globalnej populacji (FAO Statistical Yearbook 2013, 2013: 70). Jednym z państw, które nieprzerwanie od wielu lat charakteryzuje wysoki odsetek ludności dotkniętej niedożywieniem i zmagającej się z głodem, jest Sudan. Zgodnie z szacunkami FAO w latach 2010-2012 aż 39,4\% Sudańczyków, czyli około 18 mln ludzi, cierpiało z głodu i niedożywienia (The State of Food, 2012: 47). Celem artykułu jest przybliżenie zagadnienia pojęcia bezpieczeństwa żywnościowego i analiza konfliktów w sudańskiej prowincji - Darfurze, którego podstawę stanowi rywalizacja o zasoby zapewniające bezpieczeństwo żywnościowe lokalnym plemionom.

\section{DEFINIOWANIE BEZPIECZEŃSTWA ŻYWNOŚCIOWEGO}

Jak pisze Jerzy Małysz: „Dążenie do bezpieczeństwa żywnościowego, chociaż tak nie nazywane, właściwe było człowiekowi zawsze. Początkowo przejawiało się w trosce o zgromadzenie zapasów żywności, które pozwoliłyby przetrwać klęski głodu, później zaczęto dostrzegać także braki bezpieczeństwa żywnościowego w niedostatecznej sile nabywczej najuboższych warstw społeczeństwa, wreszcie - co zawdzięczamy rozwojowi nauki o żywieniu - bezpieczeństwo zaczęto także upatrywać w jakości zdrowotnej poszczególnych produktów i składającej się z nich racji żywnościowej" (Małysz, 2008: 36).

W 1984 r. Lawrance Bush i William B. Lacy dokonali w pracy pt. Bezpieczeństwo zywnościowe w Stanach Zjednoczonych (ang. Food security in the United States) oceny amerykańskiego rolnictwa i produkcji rolnej. Uznali, że bezpieczeństwo żywnościowe ma co najmniej trzy wymiary. Pierwszy z nich, to rozporządzalność (ang. availability) dotycząca stałego, zrównoważonego systemu produkcji i dystrybucji, zapewniająca dostateczną podaż żywności, tak by zaspokoić potrzeby wszystkich ludzi. System produkcji musi być również na tyle elastyczny, by nie zostać zakłócony np. przez zmienność klimatu czy niepokoje społeczne, które z kolei mogą wpłynąć na wielkość 
plonów, chów i hodowlę zwierząt. Drugim, wyróżnionym wymiarem jest dostępność (ang. accessibility), która nie powinna być ograniczona przez popyt efektywny. Każdy, bez względu na poziom dochodu i pozycję społeczną, mieszkający na wsi czy w mieście, powinien mieć dostęp do bogatych w składniki odżywcze zasobów żywności. W wolnorynkowej gospodarce każdy musi mieć do dyspozycji dochód wystarczający na zakup żywności zaspokajającej indywidualne potrzeby. Ostatni wymiar, to adekwatność/odpowiedniość (ang. adequacy), którą rozumieć można jako dostarczanie żywności pokrywającej zróżnicowane potrzeby odżywcze pośród niejednorodnych grup mężczyzn, kobiet, ludzi młodych i starszych, bogatych i biednych, tworzących narodowe i lokalne społeczności (Bush, Lacy, 1984: 2).

Joseph H. Hulse, uznając definicje L. Busha i W. L. Lacy za przydatne, dokonuje ich dalszej analizy. I tak, availability to gotowość do uzyskania pożądanego rezultatu, czyli produkcji żywności. Jest to zdolność produkcji w ilości wystarczającej do zaspokojenia wszystkich potrzeb żywieniowych ludności. Accessibility w kontekście bezpieczeństwa żywnościowego interpretuje się jako ilość żywności pokrywającą potrzeby organizmu, pozostającą w zasięgu każdego, kto musi zaspokoić uczucie głodu. Pojęcie adequacy związane jest $\mathrm{z}$ odżywcza, $\mathrm{w}$ stosunku do fizjologicznych potrzeb organizmu, adekwatnością/odpowiedniością żywności (Hulse, 1995: 11).

Polscy autorzy - Bożena Gulbicka i Jerzy Małysz, określają trzy warunki bezpieczeństwa żywnościowego:

- fizyczna dostępność żywności, przez co rozumie się jej wystarczającą podaż, którą zapewnia krajowa gospodarka żywnościowa, pokrywająca, co najmniej minimalne zapotrzebowanie fizjologiczne ludności, a także import, dostarczający żywność ponad minimalne zapotrzebowanie;

- ekonomiczna dostępność żywności oznacza, że musi być ona w niezbędnej ilości osiagalna dla każdego, nawet najbiedniejszego gospodarstwa domowego, co realizowane jest przez różne formy pomocy żywnościowej (bony żywnościowe, programy bezpłatnego rozdzielnictwa żywności dla wybranych grup, zasiłki pieniężne, dotacje cen żywności i/lub jej produkcja);

- dostęp do żywności wolnej od zanieczyszczeń oraz zapewniającej wystarczający dla organizmu poziom energii i proporcje składników odżywczych (Gulbicka, 2003: 10; Małysz, 2008: 88-164).

\section{BEZPIECZEŃSTWO ŻYWNOŚCIOWE WEDLUG FAO}

W listopadzie 1996 r., podczas Światowego Szczytu Żywnościowego (ang. World Food Summit), w przyjętym Planie Działania (ang. World Food Summit Plan of Action), w art. 1, zdefiniowano bezpieczeństwo żywnościowe jako sytuację, która istnieje, ,gdy wszyscy ludzie nieprzerwanie posiadają fizyczny i ekonomiczny dostęp do wystarczającej, bezpiecznej i bogatej w składniki odżywcze żywności, pokrywającej zapotrzebowanie na nie [...] tak, by prowadzić aktywny i zdrowy tryb życia" (World Food Summit Plan of Action, 1996). Definicja ta, obecnie powszechnie akceptowana, obejmuje następujące elementy składowe: 
- rozporządzalność (ang. food availability) odnosząca się do fizycznej dostępności żywności na różnych poziomach - od gospodarstwa domowego po poziom narodowy, pochodzącej z krajowej produkcji lub wymiany handlowej; do jej określenia FAO stosuje wskaźnik DES (ang. Dietary Energy Supply), wyrażany w kilokaloriach na osobę na dzień; na poziomie państwa to ilość żywności fizycznie dostępnej dla ludzi po odliczeniu eksportu, produkcji przeznaczonej dla zwierząt i użytej w przemyśle, nasion i odpadów (The State of Food Insecurity in the World 2006, 2006: 38);

- dostęp ekonomiczny (ang. food access) dotyczący możliwości zapewnienia odpowiedniej i zdrowej diety, co wiąże się ze środkami finansowymi/majątkiem i dochodami będącymi w dyspozycji w danym gospodarstwie domowym;

- dostęp do żywności, która zapewni organizmowi wzrost (budowę i odbudowę tkanek), wytworzenie ciepła niezbędnego do utrzymania temperatury ciała oraz dostarczy energii wszystkim procesom życiowym (Andrews, Flores, 2008: 2).

\section{WYMIARY BEZPIECZEŃSTWA ŻYWNOŚCIOWEGO}

Bezpieczeństwo żywnościowe rozpatrywane jest, co najmniej w trzech, niekiedy trudnych do rozgraniczenia wymiarach (zakresach). Pierwszy z nich to wymiar międzynarodowy, którego występowanie uświadomiono sobie, na skutek mającego miejsce w latach siedemdziesiątych XX w., kryzysu żywnościowego. Jego rezultatem był spadek światowych rezerw zbóż z poziomu zapewniającego zapasy na ponad $100 \mathrm{dni}$ w 1968 r. do 40 dni w 1974 r. Na kryzys złożyły się takie czynniki, jak: nieurodzaj zbóż w Chinach, ZSRR i na kontynencie afrykańskim (ze względu na czynniki pogodowe); wzrost cen ropy naftowej, co zwiększyło koszty paliw i nawozów używanych w produkcji rolnej, a także decyzja Związku Radzieckiego o wejściu na światowy rynek zbóż, aby pokryć spadki swoich zapasów, czego konsekwencją było zredukowanie rezerw USA i Kanady. Splot wymienionych czynników doprowadził do trzykrotnego wzrostu cen zbóż na rynku światowym w obliczu spadku ich produkcji jedynie o 3\% (Kegley, Wittkopf, 1989: 296-298). Rezultatem opisanych wydarzeń było z kolei stworzenie przez społeczność międzynarodową instytucji, których działalność miała koncentrować się na kwestiach związanych z bezpieczeństwem żywnościowym. „Potrzeba międzynarodowego bezpieczeństwa żywnościowego pojawia się wówczas, gdy jej zaspokojenie staje się warunkiem biologicznej egzystencji społeczeństw tych krajów rozwijających się, które dotknięte są trwałym deficytem żywności, produkują ją w skrajnie niedogodnych warunkach przyrodniczych, a jednocześnie nie dysponują środkami płatniczymi, aby zakupić brakującą żywność na rynku światowym. Ponieważ własne rządy nie są w stanie zapewnić bezpieczeństwa żywnościowego (tzn. narodowego), konieczna jest pomoc żywnościowa świadczona przez inne kraje bezpośrednio lub za pośrednictwem organizacji międzynarodowych" (Toczek, 1988: 29).

Węższe znaczenie międzynarodowego bezpieczeństwa żywnościowego dotyczy zapasów żywności, przede wszystkim zboża, jako podstawowego produktu diety. 
Zgodnie z wytycznymi FAO, bezpieczny minimalny poziom zapasów zbóż wynosi $17-18 \%$ światowego zużycia. W przypadku zapasów pszenicy jest to $25 \%$ światowego zużycia, a zbóż paszowych - 15\% (Toczek, 1981: 328; Gulbicka, 2003: 11). Szersza interpretacja pojęcia obejmuje wszystkie elementy systemu żywnościowego, ,włączając w to zrównoważoną produkcję żywności, pomoc żywnościową, zapasy żywności, programy wyżywieniowe, [...] dystrybucję żywności oraz nakład do jej produkcji, handel żywnością, systemy informacji dotyczące produkcji i konsumpcji żywności" (Małysz, 2008: 168). Międzynarodowe bezpieczeństwo żywnościowe może być długookresowe, co oznacza ,[...] pewność, że spożycie żywności na mieszkańca może być co najmniej utrzymane na nie zmienionym poziomie i raczej zwiększane z czasem, szczególnie w ubogich państwach” lub krótkookresowe, które definiowane jest jako: ,[...] zdolność zapobiegania gwałtownym spadkom podaży i towarzyszącym im gwałtownym wzrostom cen do poziomu zbyt wysokiego dla wielu konsumentów o niskich dochodach [...]" (Huddleston, 1977: 91).

Dwa kolejne wymiary bezpieczeństwa żywnościowego, to perspektywa narodowa i sfera gospodarstwa domowego. Następujące wskaźniki charakteryzują bezpieczeństwo żywnościowe na poziomie państwa:

- wielkość wewnętrznej produkcji surowców rolnych i żywności oraz jej rozdysponowanie;

- zapasy i rezerwy żywności;

- możliwości importu żywności;

- dostępność zagranicznych środków płatniczych;

- dynamika i podział PKB;

- fluktuacja cen żywności na rynku wewnętrznym i międzynarodowym (Gulbicka, 2003: 12).

W przypadku narodowego bezpieczeństwa żywnościowego szczególnie istotny jest stopień uzależnienia od importu podstawowych produktów żywnościowych. Uznaje się, że: „Im większy jest udział importowanych zbóż w podaży i krajowym użyciu, im więcej dochodów z eksportu przeznacza się na opłacanie importu podstawowej żywności, tym mniejsze jest bezpieczeństwo żywnościowe. Państwa, w których wyżywienie ludności w dużym stopniu zależy od importu (głównie z powodu warunków naturalnych), muszą utrzymywać duże rezerwy żywności, aby zagwarantować krajowe bezpieczeństwo żywnościowe" (Gulbicka, 2003: 13).

Wyodrębnienie bezpieczeństwa żywnościowego na poziomie gospodarstwa domowego przypada na połowę lat osiemdziesiatych XX w., gdy Afrykę dotknął kolejny kryzys żywnościowy. Stało się wtedy jasne, że rozporządzanie żywnością adekwatną do potrzeb narodowych, nie jest równoznaczne z bezpieczeństwem żywnościowym pojedynczych osób i gospodarstw domowych, co wynikało z braku ekonomicznej dostępności do niej. Tego warunku bezpieczeństwa żywnościowego nie brano wcześniej pod uwage (Frankenberger, McCaston, 1998). Usytuowanie bezpieczeństwa żywnościowego wśród innych elementów tzw. bezpieczeństwa gospodarstwa domowego przedstawia rysunek 1. 


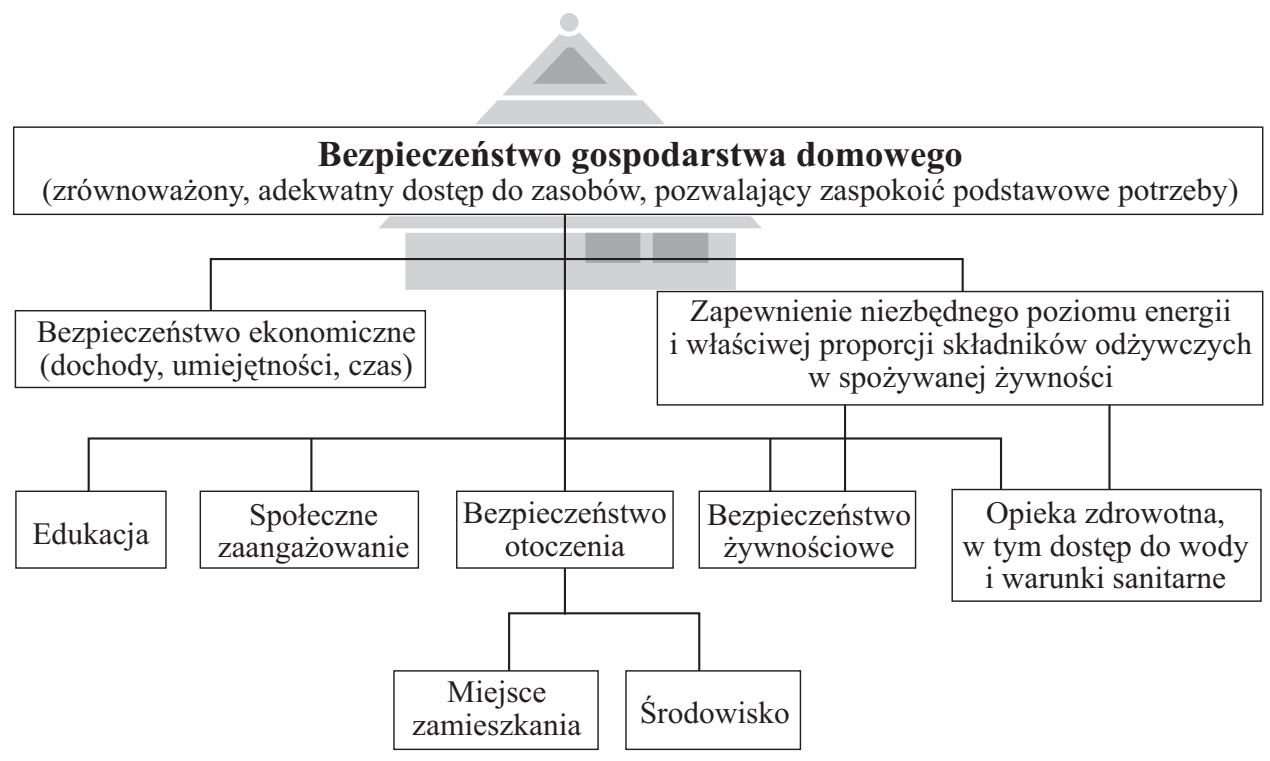

Rys. 1. Elementy składające się na bezpieczeństwo gospodarstwa domowego

Źródło: Opracowanie własne na podstawie T. R. Frankenberger, M. K. McCaston, The household livelihood security concept, „Food, nutrition and agriculture” 1998, No. 22.

\section{KONFLIKT W DARFURZE}

Darfur to zachodni region Sudanu o powierzchni porównywalnej do terytorium Francji. Administracyjnie podzielony został na trzy stany, reprezentujące etnicznie odmienne strefy zróżnicowane również pod względem ukształtowania terenu. $Z$ półpustynnego stanu Północnego pochodzą pasterze wielbłądów (nazywani Abbala) z zarówno arabskich, jak i nie arabskich ludów (największym z nich jest Zaghawa). Wodę czerpią z dolin wypełniających się wodą w czasie pory deszczowej oraz studni, z których wiele w zimie wysycha. W Darfurze Zachodnim żyją prowadzące osiadły tryb życia ludy rolnicze: Fur, Massalit, Daju i Berti. Uprawa prosa, kukurydzy, sezamu, pomidorów czy cebuli możliwa jest dzięki żyznym gruntom i opadom oraz nawadnianiu przez wody spływające z gór Dżebel Marrah. Z kolei Darfur Południowy jest zamieszkały w większości przez pasterzy bydła, zwanych Baggara, o arabskich korzeniach, mówiących po arabsku. Ich przodkowie przybyli do południowego Darfuru w XVIII w. i zakładali rodziny z Afrykanami. Wypasowi zwierząt sprzyjają zielone pastwiska istniejące dzięki obfitym wiosennym deszczom. Woda czerpana jest ze studni i tworzonych sztucznie rezerwuarów. Uprawia się tu również orzeszki ziemne, mango, drzewa cytrusowe oraz bawełnę (Collins, 2006: 3-4).

Strony zaistniałego konfliktu często określane są jako „Arabowie” i „Afrykanie”, co sugeruje, że ma on charakter rasowy bądź etniczny. Wprowadzać to może w błąd, gdyż uczestnicy sporu to ludność o tym samym kolorze skóry, wyznająca islam. Element różniący ludy Darfuru stanowi przynależność do różnych plemion, których jest około stu i przyjęty przez nie styl życia - osiadły lub koczowniczy. Wędrującą ludność 
pasterską określa się jako ,arabską”, zaś rolników związanych z uprawianą ziemią, jako ,afrykańską" (Ząbek, 2008).

Konflikty z użyciem przemocy, związane z konkurowaniem o ziemie pod uprawę i dla wypasu zwierząt w Darfurze oraz sąsiadującej z nim prowincji Kordofan, mają miejsce od co najmniej siedemdziesięciu lat, co przedstawia tabela 1.

Tabela 1

Przyczyny lokalnych konfliktów w Darfurze między rokiem 1930 a 2000

\begin{tabular}{|c|c|c|c|}
\hline L.p. & Zaangażowane plemiona & Rok & Glówna przyczyna sporu \\
\hline 1 & 2 & 3 & 4 \\
\hline 1 & Kababish, Kawahala, Berti, Medoub & 1932 & dostęp do pastwisk i wody \\
\hline 2 & Kababish, Medoub, Zyadiya & 1957 & dostęp do pastwisk i wody \\
\hline 3 & Rezeigat, Baggara, Maalia & 1968 & brak porozumienia na poziomie władz lokalnych \\
\hline 4 & Rezeigat, Baggara, Dinka & 1975 & dostęp do pastwisk i wody \\
\hline 5 & Beni Helba, Ziyadiya, Mahriya & 1976 & dostęp do pastwisk i wody \\
\hline 6 & Rezeigat z północy (Abbala), Dago & 1976 & dostęp do pastwisk i wody \\
\hline 7 & Rezeigat z północy, Bargo & 1978 & dostęp do pastwisk i wody \\
\hline 8 & Rezeigat z północy, Gimir & 1978 & dostęp do pastwisk i wody \\
\hline 9 & Rezeigat z północy, Fur & 1980 & dostęp do pastwisk i wody \\
\hline 10 & Rezeigat z północy, Bargo & 1980 & dostęp do pastwisk i wody \\
\hline 11 & Taaisha, Salamat & 1980 & brak porozumienia na poziomie władz lokalnych \\
\hline 12 & Kababish, Berti, Ziyadiya & 1981 & dostęp do pastwisk i wody \\
\hline 13 & Rezeigat, Baggara, Dinka & 1981 & dostęp do pastwisk i wody \\
\hline 14 & Rezeigat z północy, Beni Helba & 1982 & dostęp do pastwisk i wody \\
\hline 15 & Kababish, Kawahla, Berti, Medoub & 1982 & dostęp do pastwisk i wody \\
\hline 16 & Rezeigat, Mysseriya & 1983 & dostęp do pastwisk i wody \\
\hline 17 & Kababish, Berti, Medoub & 1984 & dostęp do pastwisk i wody \\
\hline 18 & Rezeigat, Mysseriya & 1984 & dostęp do pastwisk i wody \\
\hline 19 & Gimir, Fallata & 1987 & przebieg granic administracyjnych \\
\hline 20 & Kababish, Kawahla, Berti, Medoub & 1987 & dostęp do pastwisk i wody \\
\hline 21 & Fur, Bidayat & 1989 & grabieże przy użyciu broni \\
\hline 22 & Arab, Fur & 1989 & dostęp do pastwisk, rywalizacja polityczna \\
\hline 23 & Zaghawa, Gimir & 1990 & przebieg granic administracyjnych \\
\hline 24 & Zaghawa, Gimir & 1990 & przebieg granic administracyjnych \\
\hline 25 & Taaisha, Gimir & 1990 & kontrola nad ziemią \\
\hline 26 & Bargo, Rezeigat & 1990 & dostęp do pastwisk i wody \\
\hline 27 & Zaghawa, Maalia & 1991 & kontrola nad ziemią \\
\hline 28 & Zaghawa, Marareit & 1991 & dostęp do pastwisk i wody \\
\hline 29 & Zaghawa, Beni Hussein & 1991 & dostęp do pastwisk i wody \\
\hline 30 & Zaghawa, Mima, Birgid & 1991 & dostęp do pastwisk i wody \\
\hline 31 & Zaghawa, Birgid & 1991 & dostęp do pastwisk i wody \\
\hline 32 & Zaghawa, Birgid & 1991 & dostęp do pastwisk i wody \\
\hline 33 & Fur, Turgum & 1991 & kontrola nad ziemią \\
\hline 34 & Zaghawa, Arab & 1994 & dostęp do pastwisk i wody \\
\hline
\end{tabular}




\begin{tabular}{||c|l|c|l||}
\hline \hline 1 & \multicolumn{1}{|c|}{2} & 3 & \multicolumn{1}{|c||}{4} \\
\hline 35 & Zaghawa z Sudanu i Czadu & 1994 & rywalizacja polityczna \\
\hline 36 & Masalit, Arab & 1996 & $\begin{array}{l}\text { dostęp do pastwisk, brak porozumienia na poziomie } \\
\text { władz lokalnych }\end{array}$ \\
\hline 37 & Zaghawa, Rezeigat & 1997 & lokalna rywalizacja polityczna \\
\hline 38 & Kababish, Midoub & 1997 & dostęp do pastwisk i wody \\
\hline 39 & Masalit, Arab & 1998 & $\begin{array}{l}\text { dostęp do pastwisk, brak porozumienia na poziomie } \\
\text { władz lokalnych }\end{array}$ \\
\hline 40 & Zaghawa, Gimir & 1999 & $\begin{array}{l}\text { dostęp do pastwisk, brak porozumienia na poziomie } \\
\text { władz lokalnych }\end{array}$ \\
\hline 41 & Fur, Arab & 2000 & $\begin{array}{l}\text { dostęp do pastwisk, rywalizacja polityczna, grabieże } \\
\text { przy użyciu broni }\end{array}$ \\
\hline \hline
\end{tabular}

Źródło: Sudan. Post-Conflict Environmental Assessment, UNEP, Nairobi 2007, s. 82.

Jak wynika z tabeli 1, przez siedemdziesiąt lat główną przyczyną dwudziestu pięciu z czterdziestu jeden konfliktów plemiennych, które miały miejsce w latach 1930-2000, był dostęp do pastwisk i wody, niezbędnych do zapewnienia plemionom bezpieczeństwa żywnościowego. W Darfurze Północnym kwestia zasobów wodnych jest szczególnie poważna. W ciągu osiemdziesięciu lat średnie opady zmalały o 30\%. Jako źródła pięciu kolejnych konfliktów wyszczególnionych w tabeli 1 wymieniono rywalizację o pastwiska, wynikającą z ciagłego wzrostu liczebności stad zwierząt hodowlanych i postępującego pustynnienia, przyczyniającego się do szybszej erozji gleb. Od lat trzydziestych XX w. nastąpiło przesunięcie od 50 do $200 \mathrm{~km}$ na południe granicy między Saharą a półpustynnym obszarem Darfuru Północnego. W wyniku tych procesów doszło do wewnętrznych migracji na dużą skalę, głównie z północy prowincji. W centralnej części Darfuru liczba ludności wzrosła z 3 osób $/ \mathrm{km}^{2}$ w 1956 r., do 18 osób/km² w 2003 r. (Sudan. Post-Conflict Environmental Assessment, 2007: 9, 84).

Spory o kurczące się zasoby zaostrzyły się w latach 1983-1984, kiedy doszło do wielkiej suszy, która przyspieszyła pustynnienie północnego i centralnego Darfuru. Pasterze wielbłądów z północy prowincji zaczęli masowo kierować się na południe, co spowodowało, że rolnicy chcący zabezpieczyć zbiory przed zniszczeniem przez zwierzęta, blokowali dostęp do swoich pól. W rezultacie nomadzi odcięci zostali od szlaków pasterskich, wobec czego siłą starali się przedrzeć na południe. Sytuację pogarszały tradycyjne praktyki wypalania traw, które dla pasterzy były równoznaczne z niszczeniem pożywienia dla ich wygłodniałych stad. Prowadziło to do atakowania przez nomadów osiadłych rolników (Welzer, 2010: 85). Pasterze używali broni dostarczanej przez sudański rząd, pod pretekstem konieczności samoobrony przed możliwymi atakami ze strony Ludowej Armii Wyzwolenia Sudanu (ang. Sudan Peoples Liberation Army - SPLA), walczącej o autonomię dla chrześcijańsko-animistycznego południowego Sudanu (Origin of the Armed Conflicts in Darfur, 2013: 2).

Plemiona Abbala utraciły swoje stada, a wielu z ich członków zmuszonych zostało do podjęcia, uznawanej za niegodna, pracy fizycznej w rolnictwie lub mieście, co wywołało chęć odwetu. Szansa na rewanż pojawiła się, gdy w Darfurze, w marcu 2003 r. wybuchło powstanie afrykańskich ludów skupionych głównie w Ruchu Wyzwolenia Sudanu/Armii Wyzwolenia Sudanu (ang. Sudan Liberation Movement/Sudan Libera- 
tion Army - SLM/SLA) oraz Ruchu Sprawiedliwości i Równości (ang. Justice and Equality Movement - JEM) przeciw władzy w Chartumie (The UNResponds, 2005).

W wyniku wojskowego zamachu stanu od czerwca 1989 r., dyktatorskie rządy w Sudanie sprawuje jako premier, a od 1993 r. również jako prezydent, gen. Umar Hassan Ahmad al-Baszir. Stoi on na czele partii o nazwie Kongres Narodowy, do 1998 r. funkcjonującej jako Narodowy Front Islamski (The World Factbook, 2013). W państwie wprowadzono rasistowskie rozróżnienie na faworyzowanych „Arabów” i „czarnych Afrykanów”, którzy doświadczają dyskryminacji, np. w dostępie do stanowisk państwowych, awansów w armii, a przede wszystkim kurczących się zasobów i surowców, choćby wody (Ząbek, 2008).

W 1995 r. rząd sudański przeprowadził reformę administracyjną na obszarze Darfuru Zachodniego, którą jego gubernator dopełnił odgórnym podziałem ziemi należącej do osiadłych ludów Massalit na 13 emiratów, z których 6 przekazał do zagospodarowania nomadom. Ponadto rząd zastąpił tradycyjny system władzy plemiennej rolniczych ludów Darfuru Zachodniego nowym, w którym władzę powierzono członkom wędrownych plemion, mianując ich emirami. Rebelia z 2003 r. wybuchła jako skutek politycznej i ekonomicznej marginalizacji rolniczej ludności Darfuru, trwającej de facto od uzyskania niepodległości przez Sudan w 1956 r. (The Roots of the Conflict, 2010: 1-2).

Ataki oddziałów rządowych na wioski w Darfurze wsparte zostały przez członków arabskich plemion, dostrzegających w konflikcie szansę na przywłaszczenie sobie ziemi. Wielu nomadów, zwłaszcza Abbala posiadło umiejętności walki w wyniku szkoleń wojskowych, które przeszli jako członkowie Legionu Islamskiego, stworzonego przez Muammara Kaddafiego. Była to grupa najemników służąca do realizacji celów libijskiego dyktatora przy użyciu siły. Po jej rozwiązaniu w 1988 r., uzbrojeni i wyszkoleni wojownicy wrócili do swych plemion (Waal, 2004: 25-27). Z kolei pasterze Baggara z Darfuru Południowego wstępowali do stworzonej w 1986 r. przez rząd milicji, która walczyła z plemionami wspierającymi rebelię na południu Sudanu. Po zdobyciu władzy przez al-Baszira grupa ta nie została rozbrojona (Ziółkowski, 2002: 110).

Wyszkoleni do walki Abbala i Baggara chętnie zasilili bojówki tworzone z inspiracji rządu sudańskiego przez przywódców zbrojnych grup tzw. Dżandżawidów, w celu tłumienia powstania ludności negroidalnej. Słowo „Janjaweed” w języku arabskim dosłownie oznacza „diabły na końskich grzbietach” i używane jest przez mieszkańców Darfuru na określenie band złodziei i przestępców tworzonych przez członków koczowniczych plemion. Niektórzy z dowódców tych grup odsiadywali wyroki za popełnione przestępstwa, gdy w 2003 r. wybuchł konflikt. Zostali oni zwolnieni z więzienia przez sudański rząd, który powierzył im zorganizowanie paramilitarnych oddziałów do walki z rebeliantami w Darfurze (The Janjaweed and Their Ideology, 2013: 1-3). Za wstapienie w ich szeregi niektórym plemionom pasterskim władze oferowały ziemię i finansowe korzyści (What has Happened in Darfur, 2008).

W fazie eskalacji konfliktu zbrojnego wioski ,czarnych Afrykanów” były bombardowane i ostrzeliwane przez siły powietrzne Sudanu, po czym następował atak band pod wodzą Dżadżawidów. Niszczyli oni studnie, pola uprawne i zbiory ludności rolniczej, plądrowali dobytek i podpalali pozostałe po nalotach domostwa (Darfur Assault on Survival, 2006: 19-26). Najazdy Dżandżawidów cechowała szczególna okrutność. Na przykład w ciagu jednego dnia października 2006 r. zaatakowali kilka wiosek i obóz 
uchodźców w okolicach miejscowości Jebel Moon, zadając śmierć około pięćdziesięciu osobom, w tym dwudziestu sześciu dzieciom oraz ośmiu mężczyznom powyżej 70. roku życia (Dobrowolska-Polak, 2011: 184). Na podstawie amerykańskich zdjęć satelitarnych obliczono, że w ciągu niespełna dwóch lat od rozpoczęcia powstania z 600 afrykańskich wiosek, 400 zostało zniszczonych (Jagielski 2005).

Liczbę uchodźców wewnętrznych oceniono w 2005 r. na 2,5 mln (Rocznik strategiczny 2005/2006, 2006: 330). Obozy, w których przebywała ludność cywilna, tak samo jak konwoje z pomocą humanitarna, były atakowane i łupione przez zbrojne grupy dowodzone przez Dżandżawidów. Akty przemocy wobec pracowników agencji pomocowych powodowały kilkakrotne wstrzymywanie przez nie działań. Na przykład w grudniu 2004 r. po śmierci dwóch pracowników brytyjskiej organizacji Save the Children w wyniku ostrzału konwoju, ONZ zawiesiła swoje operacje humanitarne (Chronology: The Darfur Crisis, 2006: XXXII). Często dochodziło do gwałtów. W 2006 r. pracownicy ONZ donieśli o 2500 znanych im przypadków, zwłaszcza dotyczących kobiet, które opuszczając obozy by zbierać drewno stawały się ofiarami. Rzeczywistą skalę napaści seksualnych oszacowano na kilka tysięcy dziennie, które jednak nie były zgłaszane ze względu na to, że w sudańskiej kulturze gwałt uznawany jest za hańbiący i kobiety ukrywają takie zdarzenia (Trzaskowski, 2007).

$* * *$

W 2007 r. podjęte zostały po raz pierwszy rozmowy pokojowe. Unia Afrykańska i ONZ w celu przywrócenia stabilności w regionie powołały wspólną misję pokojową African Union/United Nations Hybrid Operation in Darfur (UNAMID). Początkowo czas misji określono na 12 miesięcy, jednak w wyniku braku trwałego porozumienia między walczącymi stronami działa ona nadal - w 2013 r. przedłużona została po raz kolejny o 12 miesięcy do 31 sierpnia 2014 r. (Resolution 2113, 2013: para. 1). Pierwsza rezolucja Rady Bezpieczeństwa ONZ określiła liczbę żołnierzy biorących udział w misji na 19 555, a sił policyjnych na blisko 6500 funkcjonariuszy (Resolution 2113, 2013: par. 2; Resolution 2063, 2012: par. 1).

Jednocześnie z działaniami skierowanymi na osiagnnięcie trwałego porozumienia między stronami walczącymi, podjęto inicjatywy zmierzające do pociągnięcia do odpowiedzialności osób podejrzanych o dokonanie zbrodni międzynarodowych. W marcu 2009 r. Międzynarodowy Trybunał Karny w Hadze wydał po raz pierwszy w swej historii nakaz aresztowania urzędującej głowy państwa - prezydenta al-Baszira (Rocznik strategiczny 2009/2010, 2010: 327), oskarżając go o zbrodnie wojenne (zamierzone kierowanie ataków przeciwko ludności cywilnej lub osobom cywilnym niebiorącym bezpośredniego udziału w działaniach wojennych oraz zezwolenie na grabież miast) i zbrodnie przeciwko ludzkości (zabójstwa ludności cywilnej, eksterminacja, przymusowe przesiedlenia, stosowanie tortur, gwałty) w Darfurze (Warrant of Arrest, 2009: 7-8). Według szacunków ONZ 300000 mieszkańców Darfuru zmarło w wyniku wojny, głodu i chorób, zaś al-Baszir ocenił straty ludzkie jedynie na 10000 (Sudan's Darfur conflict, 2010). Postępowanie sądowe przed MTK nie rozpoczęło się jednak z uwagi na zakaz rozpoznania sprawy pod nieobecność oskarżonego. 
Między 27 a 31 maja 2011 r. w Doha odbyła się kolejna konferencja pokojowa (UNAMID Background, 2007). Nie przyniosła ona jednak trwałego porozumienia między rywalizującymi o zasoby plemionami i Darfur nadal stanowi obszar konfliktu, gdzie ludność zmaga się z brakiem bezpieczeństwa żywnościowego. Do dziś w omawianym regionie Sudanu około 3 mln ludzi uzależniona jest od pomocy humanitarnej, w tym 1,2 mln stanowią mieszkańcy obozów dla uchodźców wewnętrznych. W wyniku starć między darfurskimi plemionami i ataków Dżandżawidów od stycznia do września 2013 r. kolejne 300000 osób musiało opuścić swoje domy. Ponadto szacuje się, że 30000 Sudańczyków uciekło do Czadu, zaś tysiące poniosło śmierć (Republic of Sudan, 2013: 2).

\section{Bibliografia}

Andrews C., Flores M. (2008), Vulnerability to Hunger. Improving Food Crisis Responses in Fragile States, United Nations University - World Institute for Development Economics Research, Research Paper No. 42.

FAO Statistical Yearbook 2013. World food and agriculture, FAO (2013), Rome.

Frankenberger T. R., McCaston M. K. (1998), The household livelihood security concept, „Food, nutrition and agriculture", No. 22.

Busch L., Lacy W. B. (1984), Food Security in the United States, Boulder-London.

Chronology: The Darfur Crisis, w: Genocide in Darfur: investigating the atrocities in the Sudan (2006), (eds.) E. Markusen, S. Totten, London.

Collins R. O. (2006), Disaster in Darfur: Historical Overview, w: Genocide in Darfur. Investigating the Atrocities in the Sudan, (eds.) S. Totten, E. Markusen, New York.

Darfur Assault on Survival. A Call for Security, Justice, and Restitution (2006), Phisicians for Human Rights, Washington.

Dobrowolska-Polak J. (2011), Ludność cywilna podczas wspótczesnych konfliktów zbrojnych, Poznań.

Gulbicka B. (2003), Bezpieczeństwo żywnościowe krajów rozwijajacych się, Warszawa.

Huddleston B. (1977), International finance for food security, Baltimore.

Hulse J. H. (1995), Science, agriculture and food security, Ottawa.

Jagielski W. (2005), Darfur - koszmar bez końca, „Gazeta Wyborcza”, 3.01.2005.

Kegley Ch. W., Wittkopf E. R. (1989), World Politics Trends and Transformation, New York.

Małysz J. (2008), Bezpieczeństwo żywnościowe jako strategiczna potrzeba ludzkości, Warszawa.

Origin of the Armed Conflicts in Darfur, Darfur Relief and Documentation Center, http://www.darfurcentre.ch/images/DRDC/About_DRDC/Origin_of_the_Armed_Conflicts_in_Darfur.pdf (10.09.2013).

Republic of Sudan - humanitarian situation and needs (2013), „ECHO Factsheet”.

Rocznik strategiczny 2005/2006. Przeglad sytuacji politycznej, gospodarczej i wojskowej w środowisku międzynarodowym Polski (2006), Warszawa.

Rocznik strategiczny 2009/2010. Przeglad sytuacji politycznej, gospodarczej i wojskowej w środowisku międzynarodowym Polski (2010), Warszawa.

Security Council's Resolution 1769 (2007), adopted by the Security Council at its $5727^{\text {th }}$ meeting on 31 July 2007, S/RES/1769(2007), 31.07.2007. 
Security Council's Resolution 2063 (2012) adopted by the Security Council at its $6819^{\text {th }}$ meeting on 31 July 2012, S/RES/2063(2012), 31.07.2012.

Security Council's Resolution 2113 (2013) adopted by the Security Council at its $7013^{\text {th }}$ meeting on 30 July 2013, S/RES/2113(2013), 30.07.2013.

Sudan. Post-Conflict Environmental Assessment, UNEP (2007), Nairobi.

Sudan's Darfur conflict (2010), BBC News, http://news.bbc.co.uk/2/hi/africa/3496731.stm (24.09.2013).

Toczek J. M. (1988), Bezpieczeństwo żywnościowe, w: Czy stać nas na samowystarczalność żywnościowq?, (red.) E. Gorzelak, Warszawa.

Toczek J. M. (1981), Niepokoje żywnościowe świata, Warszawa.

The Janjaweed and Their Ideology, Darfur Relief and Documentation Center, http://www.darfurcentre.ch/images/DRDC/About_DRDC/The_Janjaweed_and_Their_Ideology.pdf(12.09.2013).

The Roots of the Conflict (2010), Darfur Australia Network, http://www.darfuraustralia.org/files/conflict_roots.pdf (11.09.2013).

The State of Food Insecurity in the World 2006. Eradicating world hunger - taking stock ten years after the World Food Summit, FAO (2006), Rome.

The State of Food Insecurity in the World 2012. Economic growth is necessary but not sufficient to accelerate reduction of hunger and malnutrition, FAO (2012), Rome.

The UN Responds to the Crisis in Darfur: A Timeline (2005), http://www.un.org/News/dh/dev/ scripts/darfur_formatted.htm (11.09.2013).

The World Factbook (2013), https://www.cia.gov/library/publications/the-world-factbook/geos/su.html (11.09.2013).

Trzaskowski P. (2007), Gwałt narzędziem walki w Darfurze, „Gazeta Wyborcza”, 25.06.2007.

UNAMID Background (2007), http://www.un.org/en/peacekeeping/missions/unamid/background.shtml (26.09.2013).

Waal de A. (2004), Counter-Insurgency on the Cheap, „London Review of Books”, Vol. 26, No. 15.

Warrant of Arrest for Omar Hassan Ahmad Al Bashir (2009), International Criminal Court, ICC-02/05-01/09, 4.03.2009.

Welzer H. (2010), Wojny klimatyczne, Warszawa.

What has Happened in Darfur (2008), Save Darfur Coalition, http://savedarfur.org/pages/primer (12.09.2013).

World Food Summit Plan of Action (1996), World Food Summit, FAO Rome, http://www.fao.org/docrep/003/w3613e/w3613e00.htm (2.09.2013).

Ząbek M. (2008), Tragedia w Darfurze. Geneza, charakter i skutki wojny domowej, strona internetowa Polskiej Akcji Humanitarnej, http://pah.h2.pl/pomoc_humanitarna,projekty_w_darfurze,263,darfur_artykuly.html (7.09.2013).

Ziółkowski B. (2002), Konflikty zbrojne we współczesnej Afryce. Stan obecny na tle historycznym - zarys, Torun.

\section{STRESZCZENIE}

Zgodnie z definicją wypracowaną w ramach ONZ, bezpieczeństwo żywnościowe istnieje, gdy ludzie mają nieprzerwanie zapewniony „fizyczny i ekonomiczny dostęp do wystarczającej, bezpiecznej i bogatej w składniki odżywcze żywności”. Artykuł wyjaśnia kształtowanie się koncepcji bezpieczeństwa żywnościowego oraz wyodrębnienie jego trzech wymiarów 
- tj. międzynarodowego, narodowego i odnoszącego się do gospodarstwa domowego. Celem autorki jest analiza międzyplemiennych konfliktów i wojny domowej w Darfurze w kontekście rywalizacji o zasoby zapewniające bezpieczeństwo żywnościowe mieszkańcom tej sudańskiej prowincji.

\title{
FOOD INSECURITY AS A SOURCE OF ARMED CONFLICTS IN DARFUR
}

\begin{abstract}
According to the United Nations definition food security exists when people have ,at all times physical and economic access to sufficient, safe and nutritious food". This article explains approaches to the concept of food security and identifying its three dimensions, i.e. international, national and household level. The purpose of this paper is to analyse inter-tribal conflicts and civil war in Darfur in terms of competition for natural resources essential to ensure food security of province communities.
\end{abstract}

